ISSN 0258-7122 (Print), 2408-8293 (Online)

Bangladesh J. Agril. Res. 43(2): 323-332, June 2018

\title{
BIO-RATIONAL MANAGEMENT PACKAGES OF JASSID AND SHOOT AND FRUIT BORER OF OKRA
}

\author{
A. MOHAMmad ${ }^{1}$, S. N. AlAM ${ }^{2}$, M. R. U. MiaH ${ }^{3}$ \\ M. R. AMIN ${ }^{4}$ AND H. B. SAIF ${ }^{5}$
}

\begin{abstract}
The study was conducted for bio-rational management of jassid (Amrasca biguttula biguttula), and shoot and fruit borer of okra (Earias vittella) at experimental field of Bangladesh Agricultural Research Institute (BARI) during April to July 2016. Management Packages used in this study were package 1: Hand picking+ pheromone mass trapping for Earias vittella + spraying of bioneem plus 1 EC @ 1 $\mathrm{ml} \mathrm{l}^{-1}$ of water, package 2: Hand picking + pheromone mass trapping for Earias vittella + spraying of emamectin benzoate 5 SG @ $1 \mathrm{~g} \mathrm{l}^{-1}$ of water, package 3: Hand picking + pheromone mass trapping for Earias vittella + spraying of spinosad 45 SC @ $0.4 \mathrm{ml} \mathrm{l}^{-1}$ of water, package 4: Farmers practice: Spraying of cypermethrin 10 EC@ $1 \mathrm{ml} \mathrm{l}^{-1}$ of water at seven days interval, and an untreated control. Among the packages bio-neem based one (Package 1) was the best to control jassid population, emamectin benzoate based package (Package 2) was the best to control okra shoot and fruit borer infestation on shoot and spinosad based package (Package 3) was the best to control okra shoot and fruit borer infestation on fruit. Statistically similar yields were obtained from biorational package treated plots and their yields were significantly higher than farmer's practice (Package 4) and untreated control plot. Higher benefit cost ratio (4.57-9.18) was obtained from bio-rational management package treated plots compare to that of farmer's practice plot (4.50).
\end{abstract}

Keywords: Jassid, okra shoot and fruit borer, bio-rational management.

\section{Introduction}

Okra (Abelmoschus esculentus L.) is a popular vegetable in Bangladesh and grows at different parts in the world. Okra is an important summer vegetable in Bangladesh, which plays an important role to meet the demand of vegetables of the country when vegetables are scanty in the market (Rashid, 1999). Okra production in Bangladesh is affected by many factors, among them insect pest attack is major one. On okra, 72 species of insects have been recorded of which jassid, shoot and fruit borer, aphid, whitefly, mealybug, leaf roller cause significant damage (Ali et al., 2005).

${ }^{1}$ Scientific Officer, Lac Research Station, Bangladesh Agricultural Research Institute (BARI), Chapainawabganj, ${ }^{2}$ Chief Scientific Officer, Entomology Division, BARI, Gazipur, ${ }^{3,4 \& 5}$ Professor, Department of Entomology, Bangabandhu Sheikh Mujibur Rahman Agricultural University (BSMRAU), Gazipur, ${ }^{5}$ Scientific Officer, Planning \& Evaluation Wing, BARI, Gazipur, Bangladesh. 
Among the insect pests, jassid (Amrasca biguttula biguttula Ishida) and okra shoot and fruit borer (OSFB) (Earias vittella Fabricius) are the most serious pests and major limiting factors in okra cultivation. Jassids are very destructive pest of okra during seedling and vegetative stage. They suck sap from leaves, stems and developing fruits, transmit viral diseases and also inject toxic substance to plant which retards growth of the plant (Bi et al., 2001). Okra shoot and fruit borer larvae cause damage by boring into the tender shoots and fruits of okra (Rahman et al., 2013). Infested shoot wilt and dry, damage plant develop branches and produce smaller fruits. In case of infested fruit, feeding larvae and their excreta present inside the fruit which reduce marketable yield and attraction of the consumers.

Farmers frequently apply toxic insecticides to protect their crops but extensive use of insecticides leads to the problems of pest resistance, resurgence, pesticides residues, destruction of beneficial fauna and environmental pollution (Adilakshmi et al., 2008). Therefore, it is urgent to develop alternative methods of pest management other than the use of insecticides.

Different sources of bio-insecticides are being used as safe alternatives to synthetic chemical insecticides to overcome the challenges of food contamination as they are supposed to be environment friendly, safe to human and other nontarget organisms as well. Azadirachtin containing neem insecticides are well known for their safety and good performance (Schmutterer, 2002). Various findings have been published (Naqvi, 1996; Aslam and Naqvi, 2000) which endorsed their effectiveness in controlling numerous pests. Whereas spinosad, consisting spinosyns substances derived from naturally occurring soil bacterium Saccharopolyspora spinosa by aerobic fermentation of this actinomycete species, possesses both contact and stomach poisoning activity against a wide range of insect groups. Emamectin is a foliar insecticide derivative of abamectin, which is isolated from fermentation of Streptomyces avermitilis, a naturally occurring soil actinomycete. It has been registered for uses in many countries on fruits, vegetables, cereals, tree nuts, oilseeds, herbs and tea crops (Ishaaya et al., 2001).

Considering the hazardous impact of chemical insecticides, the utilization of biopesticide based management tactics are safe and hazards free and considered as environmental friendly management tactics for insects pests. So it is very much important to develop bio-rational based integrated management packages against jassid, and shoot and fruit borer of okra.

\section{Materials and Methods}

The experiment was laid out in a Randomized Complete Block Design (RCBD) with three replications in the field of Entomology Division, BARI. The whole experimental field was divided into three blocks. The unit plot size was $6 \mathrm{~m} \times 4 \mathrm{~m}$. The inter block distance was $2 \mathrm{~m}$ and inter plot distance was $1 \mathrm{~m}$ and a distance of $200 \mathrm{~m}$ was maintained between bio-rational management package treated plots 
and the farmer's practice and untreated control plots. The management package were package 1: Hand picking+ pheromone mass trapping for Earias vittella + spraying of bio-neem plus 1 EC (Azadirachtin) @ $1 \mathrm{ml} \mathrm{l}^{-1}$ of water, package 2: Hand picking + pheromone mass trapping for Earias vittella + spraying of emamectin benzoate 5 SG (Proclaim) @ $1 \mathrm{~g} \mathrm{l}^{-1}$ of water, package 3: Hand picking + pheromone mass trapping for Earias vittella + spraying of spinosad 45 SC (Tracer) @ $0.4 \mathrm{ml} \mathrm{l}^{-1}$ of water, package 4: Farmers practice: Spraying of cypermethrin $10 \mathrm{EC}$ (Ripcord) @ $1 \mathrm{ml} \mathrm{l}^{-1}$ of water at 7 days interval, Untreated control (Water spray). Management packages were applied at 12 days interval and in farmers practice plot, treatment was applied at 7 days interval. In case of management packages using hand picking of infested leaves, shoots, flower buds, fruits and destruction of insect eggs were done before spraying.

Data were collected on the basis of some pre-selected parameters, such as number of jassid leaf ${ }^{-1}$, total number of shoot and okra shoot and fruit borer (OSFB) infested shoot plant $^{-1}$, total number of fruit and OSFB infested fruit plant 1 , weight of healthy fruit, weight of infested fruit and total yield of okra.

Number of jassid leaf ${ }^{-1}$ were counted and recorded 1 day before spray (pretreated condition) and 48 hours after every spray (after treatment application) from 5 leaves of randomly selected 5 plants of each plot. Data were converted to mean jassid population leaf ${ }^{-1}$.

Total number of shoot, and OSFB infested shoot were counted and recorded from randomly selected 5 plants of each plot starting from vegetative stage and continued till last harvesting at 7 days interval. Total number of fruit and OSFB infested fruit were also counted and recorded at 7 days interval from randomly selected 5 plants of each plot. It was started from fruit initiation stage and continued till last harvest. Healthy and infested yield data were recorded at the time of harvesting of fruits. Total 18 harvests were made at every 2 to 3 days intervals at different fruiting stages ( 5 early, 8 mid and 5 late) and the yield was converted in $\mathrm{t} \mathrm{ha}^{-1}$. Forty-sixty, 61-80 and greater than 80 days old crops were considered as early, mid and late fruiting stages, respectively.

\section{Benefit cost analysis}

For benefit cost analysis, records of the costs incurred for labour, pesticides, application of pesticide in each treatment and that of control without insecticide were considered. The untreated control did not require any pest management cost. The price of the harvested marketable healthy fruit of each treatment and that of control were calculated at market rate. The result of benefit cost-analysis was expressed in terms of benefit cost ratio (BCR).

$$
\mathrm{BCR}=\frac{\text { Adjustable net return }}{\text { Total management cost }}
$$




\section{Statistical analysis}

Data were analysed by analysis of variance with the help of computer package STATISTIX 10 program. The mean differences of the treatments were observed by Least Significant Difference (LSD) test at 5\% level of probability for the interpretation of results.

\section{Results and discussion}

The number of jassid after $48 \mathrm{~h}$ of treatment application varied from 1.72 to 5.14 leaf $^{-1}$ (Table 1). Significantly lower jassid population was found among the biorational management package treated plot compared to farmer's practice and untreated control plot. The lowest jassid number 1.72 leaf $^{-1}$ was found in package 1 consisting of Hand picking+ pheromone mass trapping of E. vittella + spraying of bio-neem plus 1 EC. Second lowest jassid population was found in package 3 (Hand picking+ Pheromone mass trapping for E. vittella + spraying of spinosad $45 \mathrm{SC})$ treated plot $\left(2.36 \mathrm{leaf}^{-1}\right)$ which was statistically similar to that of package 2 (Hand picking+ pheromone mass trapping for E. vittella + spraying of emamectin benzoate $5 \mathrm{SG})\left(2.52\right.$ leaf $\left.^{-1}\right)$. The highest number of jassid was found in untreated control plot $\left(5.14\right.$ leaf $\left.^{-1}\right)$ followed by farmer's practice plot (3.19 leaf $\left.{ }^{-1}\right)$. The population reduction over pre-treated population was $67 \%, 55.55 \%$, $50.68 \%, 47.18 \%$ and $7.05 \%$ in package 1 , package 3, package 2, farmer's practice and untreated control plot, respectively. Population reduction occurs in control plot may be due to water spray.

Table 1. Effect of different bio-rational management packages on jassid population abundance in okra field after 48 hours of treatment application

\begin{tabular}{c|c|c|c}
\hline \multirow{2}{*}{ Treatments } & \multicolumn{2}{|c|}{ Mean number of jassid/ leaf } & $\begin{array}{c}\text { \% Reduction of } \\
\text { jassid population } \\
\text { over pre-treated } \\
\text { population }\end{array}$ \\
\cline { 2 - 3 } & $\begin{array}{c}\text { Before treatment } \\
\text { application }\end{array}$ & $\begin{array}{c}\text { After 48 hours of } \\
\text { treatment application }\end{array}$ & 67.04 \\
Package 1 & $5.22 \mathrm{~b}$ & $1.72 \mathrm{~d}$ & 50.68 \\
Package 2 & $5.11 \mathrm{~b}$ & $2.52 \mathrm{c}$ & 55.55 \\
Package 3 & $5.31 \mathrm{~b}$ & $2.36 \mathrm{c}$ & 47.18 \\
Farmer's practice & $6.04 \mathrm{a}$ & $3.19 \mathrm{~b}$ & 7.05 \\
Untreated control & $5.53 \mathrm{~b}$ & $5.14 \mathrm{a}$ & \\
CV \% & 4.43 & 4.10 & \\
\hline
\end{tabular}

In a column, means having similar letter(s) are not significantly different at 5\% level of significance by Least Significant Difference (LSD) test. The numerical figure within column indicates the mean of three replicates. 
Effect of different management packages on shoot infestation by okra shoot and fruit borer (OSFB) at different growth stages of okra

At vegetative stage, numerically minimum shoot infestation was found in biorational management package 2 treated plot $(2.56 \%)$ followed by package 3 $(3.12 \%)$ and package 1 treated plot $(3.33 \%)$ (Table 2). Infestation of OSFB in package 2 treated plot was not differ significantly from package 3 but from package 1. All management package treated plot showed significantly lower per cent shoot infestation than farmer's practice and untreated control plot (Table 2).

At early fruiting stage, numerically the lowest shoot infestation was found in package $2(2.46 \%)$ treated plot followed by package $3(2.80 \%)$ and package 1 (3.34\%) (Table 2). Shoot infestation in package 2 treated plot was statistically similar to package 3 but statistically different from package 1 . The highest per cent shoot infestation was found in untreated control plot $(9.62 \%)$ followed by farmers practice plot (5.98\%) and both were significantly different from all other packages (Table 2).

At mid fruiting stage, significantly lower infestation was found in three biorational management package treated plots compared to farmer's practice and untreated control plots (Table 2). Numerically the lowest shoot infestation was found in package $3(2.34 \%)$ treated plot followed by package $2(2.46 \%)$ and package $1(3.20 \%)$. Management package 2 and 3 were statistically identical and other treatments were significantly different from each other (Table 2).

Among these crop stages, the lowest shoot infestation was found in late fruiting stage having a range of $1.79 \%$ to $5.66 \%$ (Table 2). Statistically similar but numerically lower shoot infestation was found in package $3(1.43 \%)$ treated plot followed package 2 treated one $(1.79 \%)$. Among the bio-rational management packages, higher shoot infestation was found in package 1 treated plot $(2.39 \%)$ but it was significantly lower than farmer's practice (3.36\%) and untreated control plot $(5.66 \%)$ (Table2).

During the study, the mean OSFB shoot infestation was found $2.32 \%$ to $8.06 \%$. The highest shoot infestation was found in control plot $(8.06 \%)$ followed by farmer's practice plot $(4.81 \%)$. Numerically the lowest shoot infestation was found in package 2 treated plot $(2.32 \%)$ followed by package $3(2.43 \%)$ and package 1 treated plot $(3.16 \%)$. OSFB infestation in package 2 and package 3 treated plot was statistically similar but significantly different from package 1 . All bio-rational package treated plots showed significantly lower shoot infestation than farmer's practice and untreated control plot (Table 2).

Result of the present study revealed that at vegetative and early fruiting stage, the lowest shoot infestation was found in bio-rational package 2 (Hand picking+ pheromone mass trapping + emamectin benzoate $5 \mathrm{SG}$ ) treated plot and at mid and late fruiting stage, the lowest shoot infestation was found in package 3 (Hand picking + pheromone mass trapping + spinosad $45 \mathrm{SC}$ ) treated plot. The lowest 
mean shoot infestation was found in package 2 (Hand picking+ pheromone mass trapping + emamectin benzoate 5 SG) treated plot. Patra et al. (2009) observed lower shoot infestation in emamectin benzoate treated plot compared to spinosad treated plot.

Table 2. Effect of different bio-rational management packages on the incidence of okra shoot and fruit borer infestation on shoot at different growth stages of okra during April-July, 2016

\begin{tabular}{c|c|c|c|c|c}
\hline \multirow{2}{*}{ Treatments } & \multicolumn{5}{|c}{ Shoot infestation (\%) } \\
\cline { 2 - 6 } & $\begin{array}{c}\text { Vegetative } \\
\text { stage }\end{array}$ & $\begin{array}{c}\text { Early fruiting } \\
\text { stage }\end{array}$ & $\begin{array}{c}\text { Mid fruiting } \\
\text { stage }\end{array}$ & $\begin{array}{c}\text { Late fruiting } \\
\text { stage }\end{array}$ & $\begin{array}{c}\text { Mean } \\
\text { infestation }\end{array}$ \\
\hline Package 1 & $3.33 \mathrm{c}$ & $3.34 \mathrm{c}$ & $3.20 \mathrm{c}$ & $2.39 \mathrm{c}$ & $3.16 \mathrm{c}$ \\
Package 2 & $2.56 \mathrm{~d}$ & $2.46 \mathrm{~d}$ & $2.46 \mathrm{~d}$ & $1.79 \mathrm{~d}$ & $2.32 \mathrm{~d}$ \\
Package 3 & $3.12 \mathrm{~cd}$ & $2.80 \mathrm{~cd}$ & $2.34 \mathrm{~d}$ & $1.43 \mathrm{~d}$ & $2.43 \mathrm{~d}$ \\
$\begin{array}{c}\text { Farmer's } \\
\text { practice }\end{array}$ & $5.77 \mathrm{~b}$ & $5.98 \mathrm{~b}$ & $4.14 \mathrm{~b}$ & $3.36 \mathrm{~b}$ & $4.81 \mathrm{~b}$ \\
Untreated & $10.37 \mathrm{a}$ & $9.62 \mathrm{a}$ & $6.59 \mathrm{a}$ & $5.66 \mathrm{a}$ & $8.06 \mathrm{a}$ \\
control & & & & & \\
CV (\%) & 7.21 & 7.44 & 5.38 & 8.77 & 4.21 \\
\hline
\end{tabular}

In a column, means having similar letter(s) are not significantly different at 5\% level of significance by Least Significant Difference (LSD) test. The numerical figure within column indicates the mean of three replicates.

\section{Effect of different packages on fruit infestation by okra shoot and fruit borer (OSFB) at different growth stages of okra}

At early fruiting stage, numerically the lowest fruit infestation was found in the plots those received bio-rational management package $3(2.10 \%)$ followed by package $2(2.34 \%)$ and package $1(2.99 \%)$ (Table 3). Fruit infestation due to OSFB in package 3 and 2 were statistically similar but both were significantly different from IPM package 1. Significantly the highest fruit infestation was found in untreated control plot $(8.67 \%)$ followed by farmer's practice plot (4.59\%) (Table 3).

At mid fruiting stage, the lowest fruit infestation by OSFB was found in package 3 treated plot $(2.12 \%)$ which was statistically identical with that of package 2 treated plot $(2.38 \%)$ (Table 3). Among the bio-rational management packages, significantly higher fruit infestation was found in package 1 treated plot $(3.51 \%)$ but this was significantly lower than farmer's practice $(5.43 \%)$ and control plot (10.49\%) (Table 3).

Comparatively higher fruit infestation due to OSFB was found at late fruiting stage with a range of $2.61 \%$ to $11.97 \%$. Significantly the lowest fruit infestation 
was found in the plots treated with bio-rational management package $3(2.61 \%)$ followed by package $2(3.37 \%)$ and package 1 treated plot (4.10\%). Significantly the highest number of fruit infestation was found in untreated control plot (11.97\%) followed by farmer's practiced treated plot (5.82\%) (Table 3).

Mean fruit infestation range for all stage was $2.28 \%$ to $10.38 \%$. Significantly lower infestation was found in three bio-rational management packages treated plots compared to farmer's practice and untreated control plot. Numerically the lowest fruit infestation was found in package $3(2.28 \%)$ treated plot followed by package $2(2.69 \%)$ and package 1 treated plot $(3.53 \%)$. The highest percent of fruit infestation was found in untreated control plot (10.38\%) followed by farmer's practice (5.47\%). Fruit infestation due to OSFB in package 2 and 3 were statistically identical (Table 3).

The results suggested that in all the stages, numerically the lowest fruit infestation was found in bio-rational management package 3 (Hand picking + pheromone mass trapping + spinosad $45 \mathrm{SC}$ ) treated plot followed by package 2 (Hand picking+ pheromone mass trapping + emamectin benzoate $5 \mathrm{SG}$ ) treated plot. The lowest mean fruit infestation (2.28) was also found in package 3 treated plot and followed by package 2 (2.69), although both of them were statistically identical. Patra et al. (2009) and Shinde et al. (2007) found the lowest fruit infestation in spinosad treated plot.

Table 3. Effect of different bio-rational management packages on the infestation of fruit by okra shoot and fruit borer at different growth stages of okra during April-July, 2016

\begin{tabular}{c|c|c|c|c}
\hline \multirow{2}{*}{ Treatments } & \multicolumn{4}{|c}{ Infestation of fruit (\%) } \\
\cline { 2 - 5 } & $\begin{array}{c}\text { Early fruiting } \\
\text { stage }\end{array}$ & $\begin{array}{c}\text { Mid fruiting } \\
\text { stage }\end{array}$ & $\begin{array}{c}\text { Late fruiting } \\
\text { stage }\end{array}$ & Mean infestation \\
\hline IPM Package 1 & $2.99 \mathrm{c}$ & $3.51 \mathrm{c}$ & $4.1 \mathrm{c}$ & $3.53 \mathrm{c}$ \\
IPM Package 2 & $2.34 \mathrm{~d}$ & $2.38 \mathrm{~d}$ & $3.37 \mathrm{~d}$ & $2.69 \mathrm{~d}$ \\
IPM Package 3 & $2.10 \mathrm{~d}$ & $2.12 \mathrm{~d}$ & $2.61 \mathrm{e}$ & $2.28 \mathrm{~d}$ \\
Farmer's practice & $4.59 \mathrm{~b}$ & $5.43 \mathrm{~b}$ & $5.82 \mathrm{~b}$ & $5.47 \mathrm{~b}$ \\
Untreated control & $8.67 \mathrm{a}$ & $10.49 \mathrm{a}$ & $11.97 \mathrm{a}$ & $10.38 \mathrm{a}$ \\
CV (\%) & 7.90 & 7.85 & 5.36 & 4.68 \\
\hline
\end{tabular}

In a column, means having similar letter(s) are not significantly different at 5\% level of significance by Least Significant Difference (LSD) test. The numerical figure within column indicates the mean of three replicates.

The lowest yield of healthy fruit and the highest yield of infested fruit ha- were recorded in the untreated control plots. Three bio-rational packages resulted in significant increase of yield of healthy fruits and decrease of infested fruit yield over untreated control and farmers practice. 
Numerically the highest marketable yield $\mathrm{ha}^{-1}$ were recorded from bio-rational management package 1 (Hand picking+ pheromone mass trapping + spraying of bio-neem plus 1EC) (11.56 $\mathrm{t} \mathrm{ha}^{-1}$ ) followed by package 3 (Hand picking + pheromone mass trapping + spraying of spinosad $45 \mathrm{SC}))\left(11.44 \mathrm{t} \mathrm{ha}^{-1}\right)$ and package 2 (Hand picking + pheromone mass trapping + spraying of emamectin benzoate $5 \mathrm{SG})\left(11.28 \mathrm{t} \mathrm{ha}^{-1}\right)$. However no significant difference was observed among them. The lowest marketable yield was found in untreated control $(6.64 \mathrm{t}$ $\left.\mathrm{ha}^{-1}\right)$ plots and second lowest yield was found in farmer's practice plots $(8.84 \mathrm{t}$ $\left.\mathrm{ha}^{-1}\right)$. Both were significantly lowewr and differed from the bio-rational management packages.

Significantly the highest yield of infested fruit was found in untreated control plots $\left(0.96 \mathrm{t} \mathrm{ha}^{-1}\right)$ followed by farmer's practice plots $\left(0.61 \mathrm{t} \mathrm{ha}^{-1}\right)$. The yield of the infested fruit was significantly reduced in all bio-rational management packages. The marketable yield increase over control was $74.10 \%, 69.88 \%$, $72.29 \%$ under bio-rational management package 1, 2 and 3, respectively. Farmer's practice gave $33.13 \%$ marketable yield increase over control.

Table 4. Yield of okra under different bio-rational management practices against jassid and okra shoot and fruit borer infestation

\begin{tabular}{c|c|c|c}
\hline \multirow{2}{*}{ Treatments } & \multicolumn{2}{|c|}{ Yield (t/ha) } & $\begin{array}{c}\text { \% Marketable yield } \\
\text { increase over control }\end{array}$ \\
\cline { 2 - 3 } & Marketable & Infested & 74.10 \\
Package 1 & $11.56 \mathrm{a}$ & $0.34 \mathrm{c}$ & 69.88 \\
Package 2 & $11.28 \mathrm{a}$ & $0.25 \mathrm{~d}$ & 72.29 \\
Package 3 & $11.44 \mathrm{a}$ & $0.23 \mathrm{~d}$ & 33.13 \\
Farmer's practice & $8.84 \mathrm{~b}$ & $0.61 \mathrm{~b}$ & \\
Untreated control & $6.64 \mathrm{c}$ & $0.96 \mathrm{a}$ & \\
CV $(\%)$ & 3.29 & 8.34 & \\
\hline
\end{tabular}

In a column, means having similar letter(s) are not significantly different at 5\% level of significance by Least Significant Difference (LSD) test.

The highest benefit cost ratio (9.18) was obtained from the bio-rational management package 1 consisting of Hand picking + pheromone mass trapping for Earias vittella + spraying bio-neem plus 1EC. Second highest benefit cost ratio of 7.15 was recorded from the plot treated with package 2 (Hand picking + pheromone mass trapping for Earias vittella + spraying of emamectin benzoate 5 SG) followed by package 3 comprise of Hand picking + pheromone mass trapping for Earias vittella + spraying of spinosad 45 SC (4.57). The lowest benefit cost ratio 4.50 was found from the farmer's practice treated plot (Table $6)$. 
Table 6. Benefit cost analysis of different bio-rational management packages for controlling jassid and shoot and fruit borer of okra

\begin{tabular}{c|c|c|c|c|c|c}
\hline Treatments & $\begin{array}{c}\text { Marketable } \\
\text { yield t/ha }\end{array}$ & $\begin{array}{c}\text { Gross } \\
\text { return } \\
\text { TK/ha }\end{array}$ & $\begin{array}{c}\text { Cost of } \\
\text { treatment } \\
\text { TK/ha }\end{array}$ & $\begin{array}{c}\text { Net } \\
\text { return } \\
\text { TK/ha }\end{array}$ & $\begin{array}{c}\text { Adjusted } \\
\text { net return }\end{array}$ & $\begin{array}{c}\text { Marketable } \\
\text { BCR }\end{array}$ \\
\hline Package 1 & 11.56 & 404600 & 16920 & 387680 & 155280 & 9.18 \\
Package 2 & 11.28 & 394800 & 19920 & 374880 & 142480 & 7.15 \\
Package 3 & 11.44 & 400400 & 30120 & 370280 & 137880 & 4.57 \\
$\begin{array}{c}\text { Farmer's } \\
\text { practice }\end{array}$ & 8.84 & 309400 & 14000 & 295400 & 63000 & 4.50 \\
Control & 6.64 & 232400 & 00 & 232400 & - & \\
\hline
\end{tabular}

Bio-rational management package 1 consisting of hand picking and spraying of bio-neem plus $1 \mathrm{EC}$ was the most effective in controlling jassid population. Other two packages also gave significant result to control jassid population. All biorational management packages significantly controlled okra shoot and fruit borer infestation. However, package 2 consisted of Hand picking + pheromone mass trapping + spraying of emamectin benzoate $5 \mathrm{SG}$ was the best to control shoot infestation and package 3 consist of Hand picking + pheromone mass trapping + spraying of spinosad $45 \mathrm{SC}$ was the best to control fruit infestation, although both were statistically similar. Statistically identical yield was obtained from all biorational package treated plots and their yields were significantly higher than farmer's practice and untreated control plots. Higher benefit cost ratio was also obtained from bio-rational packages treated plots compared to farmer's practice plot.

Present study revealed that bio-neem based package was the best to control jassid population, emamectin benzoate based package was the best to control okra shoot and fruit borer infestation on shoot and spinosad based package was the best to control okra shoot and fruit borer infestation on fruit. Further studies are needed to know the effectiveness of the alternate and combined use of bio-neem, emamectin benzoate and spinoasd in the package against jassid, and okra shoot and fruit borer infestation.

\section{References}

Adilakshmi, A., D. M. Korat and P. R. Vaishnav. 2008. Effect of organic manures and inorganic fertilizers on the incidence of insect pests infesting okra. Karnataka J. agric. Sci. 21: 287-289.

Ali, S., M. A. Khan, A. H. S. Rashed and Y. Iftikhar. 2005. Management of yellow vein mosaic disease of okra through pesticide/bio-pesticide and suitable cultivars. Intl. J. Agric. Biol. 7: 145-147.

Aslam, M. and S. N. H. Naqvi. 2000. The efficacy of phytoinsecticide in comparison with perfekthion against sucking pests of cotton. Turk. J. Zool. 24: 403-408. 
Bi, J. L., G. R. Ballmer, D. L. Hendrix, T. J. Henneberry and N. C. Toscano. 2001. Effect of nitrogen fertilizer on cotton whitefly Bemisia argentifolii population and honeydew production. Ent. Exp. Appl. 99: 25-36.

Ishaaya, I., S. Kontsedalov, D. Mazirov, A. R. Horowitz. 2001. Biorational agentsmechanisom and importance in IPM and IRM programs for controlling agricultural pests. Zool. meded. 66(2a): 363-374.

Naqvi, S. N. H. 1996. Prospects and development of a neem based insecticide in Pakistan. Proceed. 16 ${ }^{\text {th }}$ Congr. Zool. (Islamabad 1995). 16: 325-338.

Patra, S., M. L. Chatterjee and S. Arunava. 2009. Field efficacy of insecticides for management of Earias vittella in okra. Ann. Plant Protect. Sci. 17(2): 471-472.

Rahman, M. M., M. M. Uddin, M. Shahjahan. 2013. Management of okra shoot and fruit borer, Earias vittella (Fabricus) using chemical and botanical insecticides for different okra varieties. Intl. Res. J. Appl. Life Sci. 2: 1-9.

Rashid, M. M. 1999. Bibidh shabji (Dheros), In: Shabjibiggayan (In Bangali). Rashid Publishing House, 94, Old DOHS, Dhaka-1206. Pp. 466-471.

Schmutterer, H. 2002. The Neem tree, Azadirachta indica and other meliaceous plants, $2^{\text {nd }}$ edition. Neem Foundation, Vithalnagar, Mumbai, India, P. 893.

Shinde, B. D., M. B Sarkate, P. W. Memade and Y. R Sable. 2007. Bioefficacy of botanical microbial and synthetic insecticides against okra fruit borer. Pestology. 31(3): 19.22. 